\title{
Monitoring the distribution of cadmium in sediment samples from Obajana stream in North central Nigeria
}

\author{
Edmund OKORIE* and Comfort Idowu OLORUNFEMI \\ Department of Science Laboratory Technology, School of Technology, \\ Federal Polytechnic Idah, P.M.B. 1037 Idah, Kogi State, Nigeria. \\ *Corresponding author; E-mail: e.okorieslt@yahoo.com.
}

\begin{abstract}
The distribution of cadmium species in sediments of different depths from Obajana stream was investigated by sequential extraction procedure and flame atomic absorption spectrometric detection. Index of geoaccumulation was used to assess the level of sediment pollution and it was found not to be polluted. However, the speciation results were found to contain $\mathrm{Cd}$ in the order exchangeable $>$ organic matter/sulphide $>$ residual > carbonate bound > Fe-Mn oxide at top soil and $5 \mathrm{~cm}$ depths. For $10 \mathrm{~cm}, 15 \mathrm{~cm}$ and $25 \mathrm{~cm}$ depths the observed trend in $\mathrm{Cd}$ concentration is $\mathrm{Fe}-\mathrm{Mn}$ oxide bound > exchangeable > organic matter/sulphide > residual > carbonate bound. The order of decreasing concentration of $\mathrm{Cd}$ at $20 \mathrm{~cm}$ and $30 \mathrm{~cm}$ is Fe-Mn oxide > exchangeable > residual > organic matter/sulphide > carbonate bound. The $\mathrm{Cd}$ species in the exchangeable fraction occurs mostly at the topsoil followed by $5 \mathrm{~cm}$ and decreases progressively as the depth is increased. Thus plants and animals that may be exposed to this environment may, as a result of bioaccumulation, have concentrations of $\mathrm{Cd}$ in their systems beyond the acceptable limits prescribed by world health orgnisation.
\end{abstract}

(C) 2014 International Formulae Group. All rights reserved.

Keywords: Speciation, cadmium, pollution, sediment, geoaccummulation.

\section{INTRODUCTION}

Cadmium and its compounds are part of the most hazardous pollutants in the environment. Previous and established research has indicated that sediments and dusts transported and stored in the urban environment have the potential to provide often considerable quantities of heavy metals to receiving water bodies with changing environmental conditions. Sediments that accumulate along pavements in urban environments originate mainly from atmospheric deposition and anthropogenic activities such as quarrying and construction
(Ferguson and Kim, 1991; De Miquel et al., 1997; McAllister et al., 2000, 2005).

The fate and character of heavy metals is dependent on some physico-chemical parameters which govern their availability and mobility in soil and sediment systems (tack and Verloo, 1995). These sediments depending on their binding forms are more or less available for mobilization and subsequent uptake by plants and living organisms (Förstner, 1989; Lund, 1990; Ramos et al., 1994). The cement factory in the study area in the course of its quarrying activities release fine Particles into the atmosphere which 
eventually settles and dissolves in nearby stream, thereby increasing the loadings of metals present in it. Works by various authors have shown that $\mathrm{Cd}$ compounds have found their way into modern society (IARC, 1993; WHO, 1992; Morrow, 1998; OECD, 1994; ASTDR, 1999). In humans, uptake of Cd may occur via the inhalation of contaminated air or the ingestion of food and drinking water. Workers may be exposed to the metal or its compounds present as fumes or dust in the air at the workplace.

The quality of the environment is a matter of serious concern, especially today that the consequences of human intervention are already evident. Although environment is extremely valuable for people and other organisms living in it, it is also endangered due to human activities that are continuously ruining it (Davis et al., 2006). Once absorbed, $\mathrm{Cd}$ is widely distributed and retained in the body where it accumulates throughout life.

The aim of this work was to monitor the distribution of $\mathrm{Cd}$ species at different depths in the sediments from the Obajana stream.

\section{MATERIALS AND METHODS}

\section{Geoaccumulation Index, $\mathbf{I}_{\text {geo }}$}

To ascertain the degree of contamination due to human activities and to compare $\mathrm{Cd}$ concentration that appear in different depths in the sediments, an approach known as the geoaccumulation index $\left(\mathrm{I}_{\mathrm{geo}}\right)$ was used (Müller and Suess, 1979; Förstner et al., 1993) (Table 1). A quantitative equation called the index of geoaccumulation was proposed by the authors as

$$
I_{\text {geo }}=\ln \left(C_{n} / 1.5 B_{n}\right)
$$

Where $C_{n}=$ measured concentration, $\mu \mathrm{g} / \mathrm{g}$ and $\mathrm{B}_{\mathrm{n}}=$ geoaccumulation background value, $\mu \mathrm{g} / \mathrm{g}$. The factor 1.5 is introduced as the lithologic variations of trace metals. This index $\left(\mathrm{I}_{\mathrm{geo}}\right)$ compares the measured concentration of the element in the finegrained sediment fraction $C_{n}$ with the geochemical background value $B_{n}$. The average value of $\mathrm{Cd}$ in Okene stream (which is taken as the reference) is considered as $B_{n}$ value. The index of geoaccumulation consists of seven classes whereby the highest grade (6) reflects a 100-fold enrichment above background values.

\section{Study area}

The Obajana town is located in Western part of Kogi State, Nigeria, at a latitude of $7^{0} 54^{\prime} \mathrm{N}$ and longitude $6^{0} 25^{\prime} \mathrm{E}$ (Figures 1 and 2). The inhabitants are predominantly farmers whose type are basically subsistent. The area is very rich in solid minerals and has a large deposit of gypsum. It is against the backdrop of this large mineral deposit that the Obajana cement factory was established. The factory in the course of its quarrying and milling discharge some fine particles into the surrounding. These are transported by air to the surrounding river and some are deposited on land. There is a high tendency that these fine particles may find their way into the benthic biota and health consequences as a result of its deposition may arise.

\section{Sediment sampling}

Sediment samples were collected using an Eckman sampling device from the top to $30 \mathrm{~cm}$ depth. The samples were immediately air-dried and stored in plastic containers. Other materials such as stones and plant fragments were removed by passing the dried sample through a 2-mm sieve. The sieved samples were ground to powdered form using a mortar and pestle. These powdered samples were then passed through a $75 \mu \mathrm{m}$ sieve to filter the silt/clay fraction. The silt/clay fraction are most recommended for sediment speciation studies because they generally contain the highest concentrations of pollutants, and are most readily transported in suspension in natural waters.

\section{Materials}

All reagents used are analytical grade. These include distilled water, $\mathrm{KNO}_{3}$, 
$\mathrm{CH}_{3} \mathrm{COONa}, \quad \mathrm{CH}_{3} \mathrm{COOH}, \quad \mathrm{NH}_{2} \mathrm{OH} . \mathrm{HCl}$, $\mathrm{HNO}_{3}, \mathrm{H}_{2} \mathrm{O}_{2}, \mathrm{CH}_{3} \mathrm{COONH}_{4}$. The instrument used are, $\mathrm{pH}$ meter (Hanna pH 211 Microprocessor), analytical balance (Mettler Toledo PR2002), centrifuge (IECCentra-CL), FAAS (Buck Scientific Model AVG 210 UK), mortar and pestle, Eckman sampler.

\section{Sample digestion}

The sequential extraction procedure used was the one proposed by Tessier et al. (1979). Table 2 shows the procedure used in this work. The mixtures were separated from the supernatant by 30 mins centrifugation at 10,000rpm. All fractions were subjected to analysis for Cd using Buck Scientific FAAS Model AVG 210 UK.

Table 1: Geoaccumulation index classification.

\begin{tabular}{|c|c|c|}
\hline $\begin{array}{l}\text { Geoaccumulation } \\
\text { index, } I_{\text {geo }}\end{array}$ & $\mathbf{I}_{\mathrm{geo}}$ class & Contamination intensity \\
\hline$>5$ & 6 & Very strong \\
\hline$>4-5$ & 5 & Strong to very strong \\
\hline$>3-4$ & 4 & strong \\
\hline$>2-3$ & 3 & Moderate to strong \\
\hline$>1-2$ & 2 & Moderate \\
\hline$>0-1$ & 1 & Uncontaminated to moderate \\
\hline$<0$ & 0 & Practically uncontaminated \\
\hline
\end{tabular}

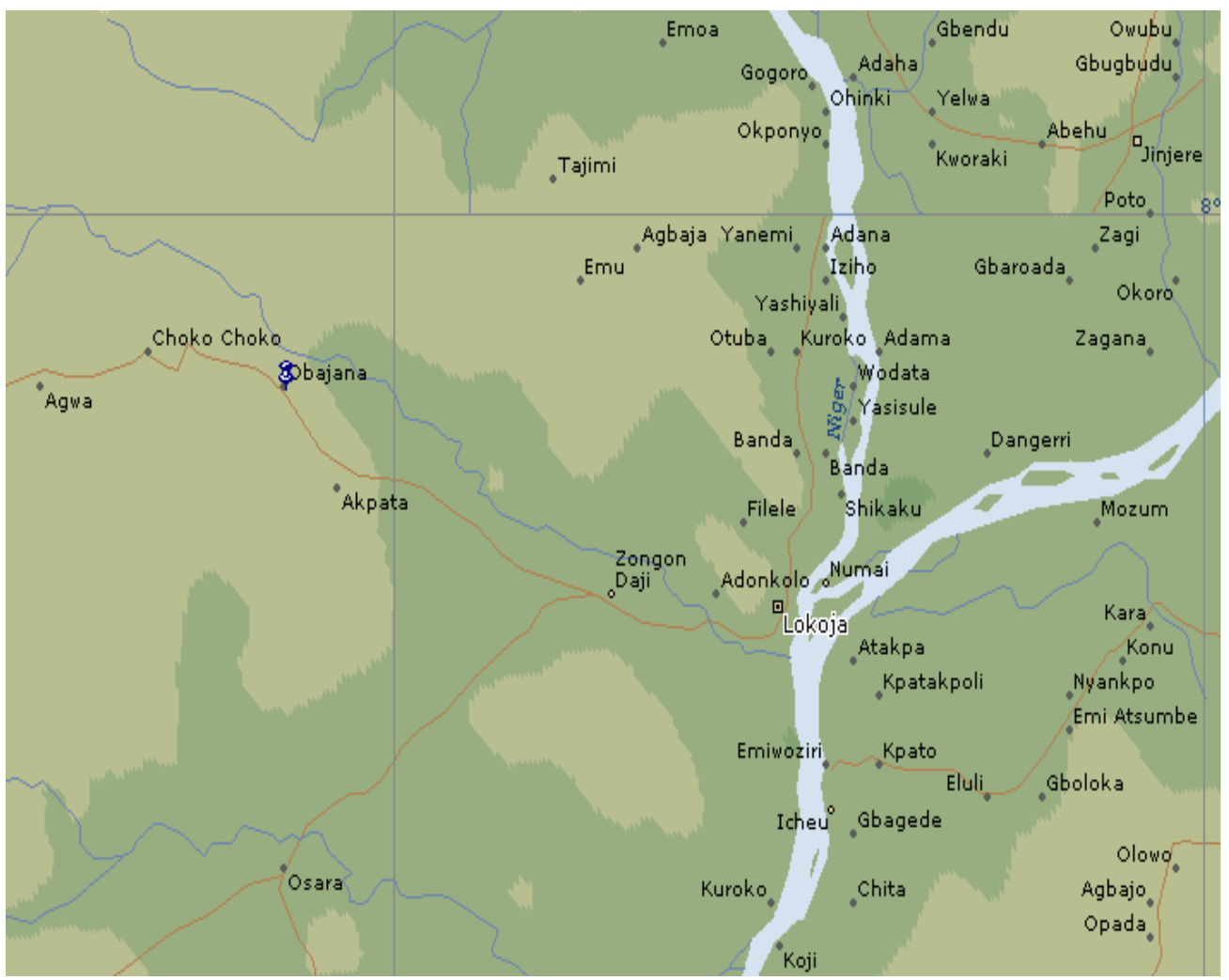

Figure 1: Map showing Obajana in Kogi State, Nigeria. 


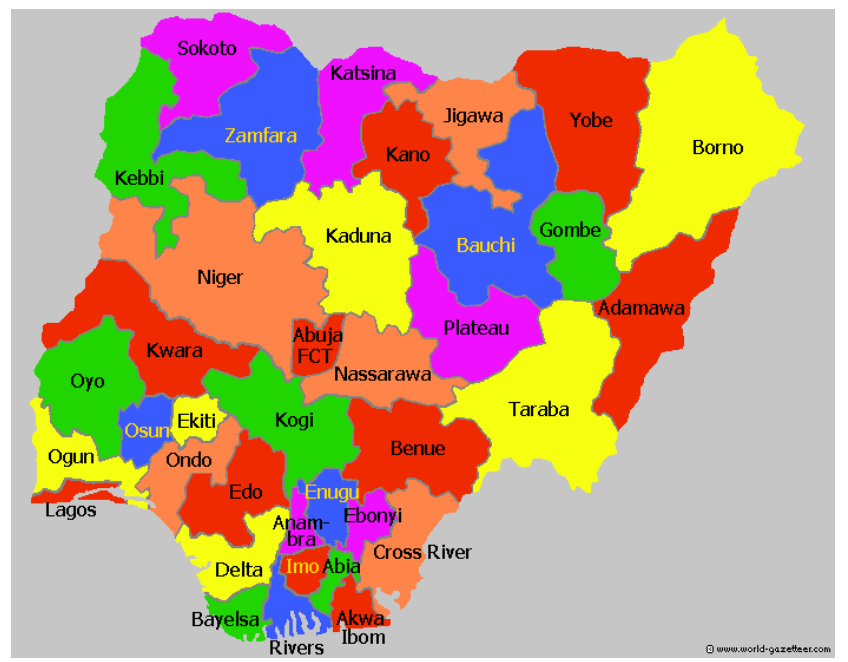

Figure 2: Map of Nigeria showing 36 states and the Federal Capital Territory.

\section{RESULTS}

The results of the monitoring of $\mathrm{Cd}$ distribution in the Obajana stream are shown in Table 3. From the results of the distribution of $\mathrm{Cd}$ in sediment samples from Obajana stream, it was observed that the exchangeable fraction which is the most lethal fraction occurred more at the topsoil $(0.097 \mu \mathrm{g} / \mathrm{g})$ followed by $5 \mathrm{~cm}$ depth $(0.092 \mu \mathrm{g} / \mathrm{g})$ and 10 cm depth $(0.072 \mu \mathrm{g} / \mathrm{g})$. At $15 \mathrm{~cm}$ depth, a concentration of $0.040 \mu \mathrm{g} / \mathrm{g}$ was recorded, however there was an increase at $20 \mathrm{~cm}$ depth $(0.047 \mu \mathrm{g} / \mathrm{g})$ followed by a decrease and an increase at $25 \mathrm{~cm}$ and $30 \mathrm{~cm}$ depths respectively. The observed $\mathrm{Cd}$ concentration was constant from topsoil to $10 \mathrm{~cm}$ depth $(0.020 \mu \mathrm{g} / \mathrm{g})$, and afterwards increased at 15 cm depth $(0.024 \mu \mathrm{g} / \mathrm{g})$ before reducing at 20 cm depth $(0.010 \mu \mathrm{g} / \mathrm{g})$. At $25 \mathrm{~cm}$ and $30 \mathrm{~cm}$ depths, Cd was not detected at this fraction.

Cadmium was not detected at the topsoil in this fraction. This trend changed from $5 \mathrm{~cm}$ depth $(0.015 \mu \mathrm{g} / \mathrm{g})$ to $30 \mathrm{~cm}$ depth $(0.090 \mu \mathrm{g} / \mathrm{g})$. The sequence decreased from $0.109 \mu \mathrm{g} / \mathrm{g}$ in $10 \mathrm{~cm}$ to $0.086 \mu \mathrm{g} / \mathrm{g}(25 \mathrm{~cm})$. The concentrations of $\mathrm{Cd}$ at the organic matter/sulphide bound fraction are considerably lower than that of Fe-Mn oxide bound. The range is $0.030-0.037 \mu \mathrm{g} / \mathrm{g}$. The residual fraction for all the sampled depths ranged from $0.181-0.262 \mu \mathrm{g} / \mathrm{g}$.

\section{DISCUSSION}

\section{Exchangeable fraction}

It can therefore be said that the exchangeable fractions decrease with increasing depth up to $15 \mathrm{~cm}$ depth. The decrease and subsequent increase at $25 \mathrm{~cm}$ and $30 \mathrm{~cm}$ is consistent for all the fractions studied. It can therefore be established that fractions at $20 \mathrm{~cm}$ depth could be referred to as the zone of transition. These elevated concentrations of $\mathrm{Cd}$ at exchangeable fraction indicate that $\mathrm{Cd}$ has posed a threat to benthic biota in the river and local residents.

\section{Fraction bound to carbonate}

Previous research on the geochemical behaviour of some heavy metal ions such as $\mathrm{Cd}^{2+}$ indicated that this metallic ion can be adsorbed onto the surfaces of carbonate minerals followed by incorporation into the crystal lattice to form $\mathrm{Cd}_{x} \mathrm{Ca}_{1-x} \mathrm{CO}_{3}$ solid solution (Billon et al., 2002). This surface phenomenon may have accounted for the observation of $\mathrm{Cd}$ from topsoil to $20 \mathrm{~cm}$ depths. 
Table 2: Extraction procedure as proposed by Tessier et al. (1979).

\begin{tabular}{|c|c|}
\hline Fractions & Procedure \\
\hline Fraction1 - exchangeable & $8 \mathrm{~mL}$ of $1 \mathrm{M} \mathrm{KNO}$ for $1 \mathrm{~h}, 25^{0} \mathrm{C}$ with continuous agitation. \\
\hline Fraction 2 - carbonate bound & $\begin{array}{l}\text { Residue from fraction } 1 \text {, add } 8 \mathrm{~mL} \text { of } 1 \mathrm{M} \mathrm{CH}_{3} \mathrm{COONa} \text {; } \mathrm{pH} 5.0 \text { adjusted with } \mathrm{CH}_{3} \mathrm{COOH} \text { and continuous agitation for } 4 \\
\text { hrs. }\end{array}$ \\
\hline Fraction3 - Fe-Mn oxide bound & $\begin{array}{l}\text { Residue from fraction } 2 \text {, add } 20 \mathrm{~mL} \text { of } 0.04 \mathrm{M} \mathrm{NH} \mathrm{NH}_{2} \mathrm{OH} . \mathrm{HCl} \text { in } 25 \%(\mathrm{v} / \mathrm{v}) \mathrm{CH}_{3} \mathrm{COOH} \text { and heated to } 96 \pm 3{ }^{\circ} \mathrm{C} \text { with } \\
\text { occasional agitation for } 6 \mathrm{hrs} \text {. }\end{array}$ \\
\hline $\begin{array}{l}\text { Fraction } 4 \text { - organic } \\
\text { bound }\end{array}$ & $\begin{array}{l}\text { Residue from fraction } 3 \text {, add } 3 \mathrm{~mL} \text { of } 0.02 \mathrm{M} \mathrm{HNO}_{3} \text { and } 5 \mathrm{~mL} \text { of } 30 \% \mathrm{H}_{2} \mathrm{O}_{2} \text { (adjusted to } \mathrm{pH} 2 \text { with } \mathrm{HNO}_{3} \text { ). Heated to } 85 \\
\pm 2{ }^{0} \mathrm{C}, 2 \mathrm{hrs} \text { with occasional agitation. A second } 3 \mathrm{~mL} \text { of aliquot of } 30 \% \mathrm{H}_{2} \mathrm{O}_{2}\left(\mathrm{pH} 2 \mathrm{with} \mathrm{HNO}_{3} \text { ) is added and the }\right. \\
\text { mixture is heated again to } 85{ }^{\circ} \mathrm{C} \text { for } 3 \mathrm{hrs} \text { with intermittent agitation. After cooling, } 5 \mathrm{~mL} \text { of } 3.2 \mathrm{M} \mathrm{CH}_{3} \mathrm{COONH}_{4} \text { in } 20 \% \\
\text { (v/v) } \mathrm{HNO}_{3} \text { is added and mixture diluted to } 20 \mathrm{~mL} \text { and agitated continuously for } 30 \text { mins. }\end{array}$ \\
\hline Fraction5 - residual & Residue from fraction 4, add $5 \mathrm{~mL} \mathrm{HNO}_{3}+\mathrm{HClO}_{4}(4: 1)$ for $2 \mathrm{hrs}$ at $96 \pm 3^{\circ} \mathrm{C}$ with intermittent agitation. \\
\hline
\end{tabular}

Table 3: Results of speciation of Cd at various depths.

\begin{tabular}{|c|c|c|c|c|c|c|c|c|}
\hline \multirow{2}{*}{$\begin{array}{l}\text { Depths } \\
\text { (cm) }\end{array}$} & \multicolumn{6}{|c|}{ Fractions concentration, $\mu \mathrm{g} / \mathrm{g}$} & \multirow[t]{2}{*}{$\mathbf{I}_{\text {geo }}$} & \multirow{2}{*}{$\begin{array}{c}\text { Contamination } \\
\text { intensity }\end{array}$} \\
\hline & Exchangeable & $\begin{array}{c}\text { Carbonate } \\
\text { bound }\end{array}$ & $\begin{array}{l}\text { Fe-Mn oxide } \\
\text { bound }\end{array}$ & $\begin{array}{c}\text { Organic matter/sulphide } \\
\text { bound }\end{array}$ & Residual & $\begin{array}{c}\text { Total Cd in } \\
\text { sediment }\end{array}$ & & \\
\hline 0 & 0.097 & 0.021 & ND & 0.037 & 0.026 & 0.181 & 0.19 & Not polluted \\
\hline 5 & 0.092 & 0.021 & 0.015 & 0.037 & 0.025 & 0.190 & 0.24 & Not polluted \\
\hline 10 & 0.072 & 0.021 & 0.109 & 0.032 & 0.028 & 0.262 & 0.56 & Not polluted \\
\hline 15 & 0.040 & 0.024 & 0.094 & 0.031 & 0.028 & 0.217 & 0.37 & Not polluted \\
\hline 20 & 0.047 & 0.010 & 0.092 & 0.032 & 0.034 & 0.215 & 0.36 & Not polluted \\
\hline 25 & 0.036 & ND & 0.086 & 0.030 & 0.028 & 0.180 & 0.18 & Not polluted \\
\hline 30 & 0.042 & ND & 0.090 & 0.031 & 0.032 & 0.195 & 0.26 & Not polluted \\
\hline
\end{tabular}




\section{Fraction bound to Fe-Mn oxide}

Due to their chemical characteristics, Fe and Mn extracted by hydroxylamine hydrochloride solution are regarded as amorphous hydrous Fe-Mn oxides in sediments or soils (Ariza et al., 2000). Much of the observed $\mathrm{Cd}$ was detected at this fraction and this plausibly suggests that hydrous Fe-Mn oxides may play a major role in controlling the fate and transport of $\mathrm{Cd}$ in the sediments of Obajana stream.

\section{Fraction bound to organic matters and sulphides}

Previous studies has proved that $\mathrm{Cd}^{2+}$ has a strong affinity for chloride ion but a weak affinity for organic matter compared to many trace metals in sea water (Tipping et al., 1998). Thus, Cd may exist in chlorocomplexes forms rather than free $\mathrm{Cd}^{2+}$ in various sediment and water samples. Therefore, the adsorption on Fe-Mn oxides and coordination with organic matter are appreciably hindered due to the decreased availability of free $\mathrm{Cd}^{2+}$ ions despite that these materials have a strong affinity for $\mathrm{Cd}^{2+}$ (Turner et al., 2008). These low values of $\mathrm{Cd}$ at this fraction may also be explained in terms of the fact that $\mathrm{Cd}$ bound to acid volatile sulphides can be liberated rapidly as a result of aeration of sediments and elevated oxygen level can significantly increase the bioavailability of $\mathrm{Cd}$ in sediments (Zhuang et al., 1994; Schaanning et al., 1996).

\section{Residual}

This fraction is less toxic for organisms in aquatic environment. For this study, the bulk of $\mathrm{Cd}$ are in the residual phase. From the geoaccumulation index, $\mathrm{Cd}$ in Obajana stream falls within the not polluted to moderately polluted class. The stream can therefore be considered fit for benthic biota. However, bioaccumulation may set in with the continual discharge of $\mathrm{Cd}$ into the water body.

\section{Conclusion}

The distribution of $\mathrm{Cd}$ in sediment samples from Obajana stream revealed that the $\mathrm{Cd}$ species occur in the fractions in the following order in the topsoil and $5 \mathrm{~cm}$ depth: exchangeable > organic matter/sulphide bound $>$ residual $>$ carbonate bound $>$ Fe-Mn oxide bound. The observed order for $10 \mathrm{~cm}$, $15 \mathrm{~cm}$ and $25 \mathrm{~cm}$ depths is: Fe-Mn oxide bound > exchangeable > organic matter/sulphide bound $>$ residual $>$ carbonate bound. The order of decreasing $\mathrm{Cd}$ concentrations in $20 \mathrm{~cm}$ and $30 \mathrm{~cm}$ depths is $\mathrm{Fe}-\mathrm{Mn}$ oxide bound $>$ exchangeable $>$ residual $>$ organic matter/sulphide > carbonate bound. The $\mathrm{Cd}$ specie in all the fractions is not polluting the Obajana stream from the geoaccumulation index.

\section{REFERENCES}

Ariza JLG, Giraldez I, Sanchez-Rodas D, Morales E. 2000. Metal sequential extraction procedure optimized for heavily polluted and iron oxide rich sediments. Anal. Chim. Acta, 414:151164.

ATSDR. 1999. Agency for Toxic Substances and Disease Registry, Cadmium (update), Toxicological Profile. US Department of Health and Human Services, ATSDR: Atlanta GA.

Billon G, Ouddanne B, Recourt P, Boughriet A. 2002. Depth variability and some geochemical characteristics of $\mathrm{Fe}, \mathrm{Mn}$, $\mathrm{Ca}, \mathrm{Mg}, \mathrm{Sr}, \mathrm{S}, \mathrm{P}, \mathrm{Cd}$ and $\mathrm{Zn}$ in anoxic sediments from Authie Bay (Northern France). Estuarine, Coastal and Shelf Science, 55: 167-181.

Davis EB. 2006. Trends in Environmental Research. Nova Science Publishers, Inc: New York, USA.

De Miquel E, Llamas JF, Chacon E, Berg T, Larsen S, Royset O, Vadsen M. 1997. Origin and patterns of distribution of trace elements in street dusts: unleaded petrol and urban lead. Atmos. Environ., 31: 2733-2740.

Ferguson JE, Kim N. 1991. Trace elements in street and house dusts source and speciation. Sci. Total Environ., 100: 125150.

Förstner U. 1989. Contaminated Sediments. Springer Verlag: Berlin; 159.

Forstner U, Ahlif W, Calmano W. 1993. Sediment quality objectives and criteria development in germany. Water Sci. Technol., 28: 307. 
IARC (International Agency for Research on Cancer). 1993. Cadmium and Cadmium compounds, in Beryllium, Cadmium, Mercury and Exposures in the Glass Manufacturing Industry (vol 58). IARC: Lyon; 110-237.

Lund W. 1990. Speciation analysis - why and how? Fres. J. Anal. Chem., 337: 557-564.

McAllister JJ, Smith BJ, Baptista Neto JA. 2000. The presence of calcium oxalate dehydrate (weddellite) in street dusts from Niteroi, Brazil and its health implications. Environ. Geochem. Health, 22: 195-210.

McAllister JJ, Smith BJ, Baptista Neto JA, Simpson JK. 2005. Geochemical distribution and bioavailability of heavy metals and ocalate in street sediments from Rio de Janeiro, Brazil: a preliminary investigation. Environ Geoch Health, 27: 429-441.

Morrow H. 1998. The importance on recycling to life cycle analysis of nickel cadmium batteries, in Proceedings of the eight International Nickel Cadmium Battery Conference, Prague, Czech Republic.

Müller PJ, Suess E. 1979. Productivity, sedimentation rate and sedimentary organic matter in the oceans. I. organic carbon presentation. Deep Sea Res., 26: 1347

OECD (Organisation for Economic Coorperation and Development). 1994. Risk Reductions Monograph No 5: Cadmium, OECD, Paris.

Petersen W, Wallmann K, Schroer S, Schroeder F. 1993. Studies on the adsorption of cadmium on hydrous iron (III) oxides in oxic sediments. Anal. Chim. Acta, 273: 323-327.

Ramos L, Hernandez LM, Gonzalez MJ. 1994. Sequential extractions of copper, lead, cadmium, and zinc in soils from or near Donama national park. J. Environ. Qual., 23: 50-57.

Schaanning MT, Hylland K, Eriksen DO, Bergan TD, Gunnarson JS, Skei J. 1996. Interactions between eutrophication and contaminants. II. Mobilization and bioaccumulation of $\mathrm{Hg}$ and $\mathrm{Cd}$ from marine sediments. Marine Pollution Bulletin, 33: 71-79.

Tack FMG, Verloo MG. 1995. Chemical speciation and fractionation in soil and sediment heavy metal analysis: a review. Int. J. Environ. Anal. Chem., 59: 225-238.

Tessier A, Campbell PGC, Bisson M. 1979. Sequential extraction procedure for the speciation of particulate trace metals. Analytical Chemistry, 51: 844-850.

Tipping E, Lofts S, Lawlor AJ. 1998. Modeling the chemical speciation of trace metals in the surface waters of the Humber system. Sci. Total Environ., 210: 63-77.

Turner A. 2000. Trace metal contamination in sediments from U.K. estuaries: An empirical evaluation of the role of hydrous iron and manganese oxides. Estuarine, Coastal and Shelf Science, 50: 355-371.

Turner A, LeRoux SM, Millward GE. 2008. Adsorption of cadmium to iron and manganese oxides during estuarine mixing. Marine Chemistry, 108: 77-84.

WHO (World Health organisation). 1992. Environmental Health Criteria 134: Cadmium, IPCS, WHO, Geneva.

Zhang YY, Allen HE, Fu GM. 1994. Effect of aeration of sediment on cadmiumbinding. Environ. Toxicol. Chemistry, 13: 717-724. 